\title{
Counterproductive Work Behaviors: a Socio-Demographic Characteristic-Based Study among Employees in the Nigerian Maritime Sector
}

\author{
Ignatius Ikechukwu UCHE, ${ }^{*}$ Olusoji GEORGE, ${ }^{2}$ \\ Wuraola ABIOLA ${ }^{3}$
}

${ }^{1}$ Department of Business Administration, University of Lagos, Lagos, Nigeria *Corresponding author: e-mail: godnear2000@yahoo.com

Telephone: +234-803-3032909

${ }^{2}$ Department of Business Administration, University of Lagos, Lagos, Nigeria E-mail: golusoji@unilag.edu.ng

${ }^{3}$ Department of Business Administration, University of Lagos, Lagos, Nigeria E-mail: wura_abiola@mtransformation.com

\begin{abstract}
The prevalence of counterproductive work behavior (CWB) does not only differ across industries but also varies significantly according to sociodemographic characteristics. This study examines CWB and socio-demographic characteristics among selected employees in the Nigerian maritime industry. Causal research design was adopted to survey 1,000 employees selected through multistage sampling approach in three selected parastatals (Nigerian Ports Authority, Nigerian Maritime Administration and Safety Agency, and Nigerian Shippers Council). The data obtained were analyzed with ANOVA and t-test. Based on the analysis carried out, CWB was found to be significantly related to gender, age, marital status, employee cadre, and income, while employees' level of educational attainment is not significantly related to CWB. Based on the abovementioned findings, the study concludes that the level of education is not significantly connected to the employees' propensity towards CWB, while other socio-demographic variables are strongly associated to CWB in the workplace. The study recommends that management should develop a mechanism for identifying and selecting their potential employees as a guide against poor organizational fit of employees and that of the organization. Likewise, effort should be intensified to develop and improve organizational culture that will propel citizenship behavior in the workplace.
\end{abstract}

Keywords: demographic characteristics, counterproductive work behaviors, workplace, employee, organizational fits, organizational culture

JEL Classifications: Mo, L32 


\subsection{Background to the Study}

There is a growing concern among organizational researchers and practitioners on the subject matter of counterproductive work behaviors (CWBs). Counterproductive behavior, often termed deviant behavior, at workplace has appeared as a foremost issue for academics as well as business executives in organizations due to its substantial cost and disrupting tendency. Thus, every business strives to limit the impacts and prevalence of these harmful behaviors (Penny \& Spector, 2005; Yang \& Diefendorff, 2009). According to Spector and Fox (2005), CWBs vary from common destructive actions - since they are not accidental and are done purposively to causing damage through deliberate actions. Business organizations represent settings where multiplicities of different behaviors are articulated, with varying degrees of consequence to the individuals as well as the entire organization (Pelin \& Funda, 2013). However, in the contemporary business world, where firms continue to struggle to endure or acquire sustainable competitive advantage, it is vital for companies to seek a thorough understanding of the issues that influence employeeoriented work outcomes (Lasisi, Okuneye, and Shodiya, 2014).

As a result, employee behavior in the workplace in terms of what they say and do has emerged as a major concern in organizations (Hiriyappa, 2008). Essentially, these behaviors can be categorized into those that benefit the organization and those that are detrimental to its success (Spector \& Fox, 2005). These damaging or dysfunctional behaviors have been considered and labeled with different terminologies by different scholars. For instance, anger (Neuman \& Baron, 1997), workplace violence (Barling, Dupre, and Kelloway, 2009), revenge (Skarlicki \& Folger, 1997), intimidation (Hoel, Rayner, and Cooper, 1999), emotional vindictiveness (Keashly, 1998), bottleneck (Zapf \& Einarsen, 2005), stealing (Greenberg, 1990), sabotage (Ambrose, Seabright, and Schminke, 2002), rudeness (Andersson \& Pearson, 1999), or dispute (Kelloway, 2010) among others. A critical evaluation of the above labels reveals that all forms of deviant behavior have harmful effects; hence, they are termed counterproductive work behaviors (CWBs). Counterproductive work behaviors can be defined as behaviors that contradict and inhibit the attainment of organizations' objectives (Spector, Fox, Penney, Bruursema, Goh, and Kessler, 2006).

Apart from personality traits (such as narcissism, agreeableness, negative emotions, etc.) that propel deviant behaviors, CWB can also result from vague job description, job insecurity, poor motivation, poor organizational control, injustice, poor career opportunities, stress, and wrong performance appraisal system among others (Shamsudin, Subramaniam, and Ibrahim, 2011; Aftab \& Javed, 2012; Fatima, Atif, Saqib, and Haider, 2012). Likewise, socio-demographic characteristics, such as age, gender, marital status, income, and level of education, are significantly connected to the tendency to engage in CWBs (Paul-Titus, 2009). 
CWBs occur either at i) interpersonal level or ii) organizational level; CWBs at interpersonal level are directed at individuals/employees within the organization - i.e. violence, verbal abuse and gossip, assault, harassment, etc. (Spector \& Fox, 2005). CWBs at the organizational level relate to deviant behaviors, such as calling in sick when one is not, withdrawal efforts, long hours of break, cyberloafing, misuse/damage of the employer's assets, stealing, sabotage, etc., which affect the organization (Chang \& Smithikrai, 2010).

Either at the individual or organizational level, the costs of CWB are very damaging to the organization in terms of declining productivity, greater maintenance costs due to vanished or destroyed property, psychological costs, and poor corporate image (Vigoda, 2002; Aquino, Galperin, and Bennett, 2004). According to Dineen and Lewicki (2006), over $\$ 50$ billion is estimated annually as the costs of fraud and theft committed by employees.

The Nigerian maritime sector accounts for a significant share of the output of service industry, and the sector is absolutely vital to the socio-economic growth and development of Nigeria. It is the foremost mode for internal trade facilitations, and, like the rest of the countries in the world, Nigeria relies on its sea ports as a major source of revenue (Nagle, 2009). In the maritime sector, CWBs manifest in such acts as theft, fraud, falsification of documents, underdeclaration of goods with insider connivance, espionage, pilferage, diversion of imported goods, vandalism, sabotage, and poor service quality, among others, which are witnessed on a daily basis.

The outline for discussion will include but is not limited to the following: background to the study, statement of the problem, theoretical and literature review, research methodology, results and discussion, conclusions, implications of the study, and recommendations for further studies.

\subsection{Statement of the Problem}

While some employees show serious concern for and make meaningful contributions to their job by performing beyond the call of their responsibilities set in their jobs, others choose to not exhibit such appropriate work behaviors, mostly when such behavior does not appeal to any direct or indirect value (Pelin \& Funda, 2013). This scenario is perhaps responsible for the decline in performance and service delivery in the public sector in general and in the maritime sector in particular. Recently, the indications of imminent managerial failure have become obvious going by the revelation of the level of fraud in various government establishments in Nigeria and poor guilt proneness displayed by the culprits. This is evident from the frequency of reports in the newspapers and other media regarding cases involving dishonesty, poor job attitude, fraud, or embezzlement, to mention but a few. Ironically, it has become a norm for public officers to request or expect 
some kind of inducement (popularly called gratification or tips) to do a job they have originally been employed to do. CWBs are like a windstorm, which if left unrestrained have the potential to erode the organizational competences and drive such firms to extinction.

According to Uchenna (2013), while it may not be formerly detailed, the fact remains that by nature and intention most employees will perpetrate some form of CWB at a given point. The above scenarios have raised concerns about the ethics in the public sector and the need to understand these occurrences in order to restrict and tackle them. A review of extant literature reveals that studies on the notion of counterproductive work behaviors (CWBs) has had abundant considerations on the part of Western researchers (Sharizan, Abdul Rahman, and Noor, 2013). Gabriel (n.d.) posits that there is a strong dispositional dimension to the propensity to either engage or withhold appropriate organizational citizenship behavior in the workplace. Thus, CWBs may share attributes that are both impulsive and instrumental forms of antisocial behaviors (Mario, 2012). Therefore, a thorough understanding of employee personality and socio-demographic variables is an important step towards a better understanding and approach to the amelioration of CWB impacts in workplaces.

Regrettably, extant literature has shown that socio-demographic characteristics have not enjoyed serious research attention in CWB studies, and the few conducted researches offer conflicting evidence regarding the relationships among sociodemographic characteristics and CWB (Robinson \& Greenberg, 1998; Peterson, 2002; O'Fallon \& Butterfield, 2005; Paul-Titus, 2009). Consequently, more empirical evidence is needed regarding the aforesaid relationship to fill this important lacuna in literature. As such, the primary purpose of this study is to investigate whether CWBs differ significantly with respect to socio-demographic variables (such as age, sex, marital status, level of education, and income) among the selected employees in the Nigerian maritime industry.

\subsection{Research Hypotheses}

To achieve the research objective, this study hypothesized that counterproductive work behaviors are not significantly different with respect to socio-demographic variables (such as age, sex, marital status, levels of educational, and income) among the selected employees in the Nigerian maritime industry. Accordingly, this hypothesis was broken down into six sub-hypotheses as follows:

1. There is no significant difference between gender and counterproductive work behaviors among the selected employees in the Nigerian maritime industry. 
2. There is no significant difference between age and counterproductive work behaviors among the selected employees in the Nigerian maritime industry.

3. There is no significant difference between marital status and counterproductive work behaviors among the selected employees in the Nigerian maritime industry.

4. There exists no significant difference between the level of education and counterproductive work behaviors among the selected employees in the Nigerian maritime industry.

5. There exists no significant difference between occupation and counterproductive work behaviors among the selected employees in the Nigerian maritime industry.

6. There is no significant difference between the level of income and counterproductive work behaviors among the selected employees in the Nigerian maritime industry.

\section{Theoretical and Literature Review}

\subsection{The Employee Fraud Triangle Theory}

Academics at DePaul University in Chicago articulated the "Employee Fraud Triangle" theory, which offers a rational theory of employees' criminal and deviant behaviors in the workplace (Cressey, 1973). The employee fraud triangle theory heavily focuses on the attitudinal elements of the employee. Essentially, this theory identifies three forces (Need, Opportunity, and Rationalization) which influence an employee's tendency to engage in unethical behaviors such as theft, abuse, withdrawal of efforts, and other forms of counterproductivity. According to this theory, when an employee is confronted with these three forces, the odds of engaging in deviant behaviors become very high.

The first element in the employee fraud triangle is the need or motivation, which may also be termed incentive - the presence of a pressure or the financial need of the person (i.e. debts or inability to meet basic needs among others) who commits fraud that drives him/her to engage in fraud. Then, the opportunity to commit fraud opens up when such (an) employee(s) gain(s) access to assets and information that allows them to both commit and conceal the fraud. The final element of the theory is the rationalization of the fraudulent behavior, which regulates the reasons advocated by the perpetrators of the deviant acts - i.e. being unpaid, suffering salary cuts, etc. This theory is particularly relevant to this study given the turbulent economic downturn the country is experiencing. According to Deloitte Financial Advisory Services (2008), during economic recession, 
employees' tendency to engage in on-the-job deviant behavior for financial gain is higher. Likewise, unemployment, loss of job, and unpaid salaries are currently becoming uncontrollable in Nigeria with 27 states in Nigeria being unable to pay the workers' salaries (Business News, 2016). The loss of these rights and privileges may propel employees to steal or engage in on-the-job dishonest behaviors.

\subsection{Defining Counterproductive Work Behavior}

As a result of growing interest and concern regarding the phenomenon of CWBs, diverse terminologies, which inferred the same meaning, have surfaced in literature. Some of these expressions are: structural crime, firm-motivated violence, avenging behaviors, bullying, and antisocial behavior in organizations among others. Counterproductive work behaviors are forms of intentional acts displayed by employees, which are viewed by the organization as conflicting to its legitimate interests (Sackett, 2002). According to Spector et al. (2006), counterproductive work behaviors (CWBs) are volitional behaviors that are destructive or intentionally designed to harm employees or organizations.

CWBs, according to Idiakheua and Obetoh (2012), are sets of undesirable acts that are damaging to the organization and harmful to its employees. Employee deviant behavior is considered voluntary probably because he/she lacks the enthusiasm to comply with the normative expectations of the social context, or they develop enough zeal to disrupt those expectations (Robinson \& Bennett, 1995). According to Lawrence and Robinson (2007), CWB is a form of organizational resistance that inhibits the attainment of organizational goals; such misbehavior intends to benefit the individual or to inflict damage on the organization (Vardi \& Weitz, 2004). While there is some overlap between the forms of counterproductive behavior, Pearson, Andersson, and Porath (2005) highlighted the following as the common features of CWBs:

i) willingness to harm (which may be lacking, existing, or unclear);

ii) object of attack (which may be individuals, the firm, or both);

iii) types of disrupted procedures (of the general public, firm, operational group, or none);

iv) occurrence of the act (a single act or repetitive);

v) degree and gravity of behaviors.

\subsection{Dimensions of Counterproductive Work Behavior}

As earlier noted, CWBs embrace a multiplicity of behaviors such as absenteeism, dissemination of destructive reports, disruption, stealing, sexual harassment, or uncooperative attitude among others (Chang \& Smithikrai, 2010). The diversity 
of these detrimental acts can be categorized into five main classes, namely: abuse, production deviation, sabotage, theft, and withdrawal (Spector et al., 2006). In general, scholars have most often used the structure established by Fox and Spector (1999) when deliberating on CWBs. Accordingly, CWB is any act anticipated to hurt the organization or other members of the organization. Hence, it can be classified around the target of the behavior: the organization (CWB-O) and other individuals (CWB-I). Behaviors such as violence and antagonism are directed at people (CWB-I), while others, such as sabotage and withdrawal of efforts, are focused on organizations (CWB-O). Additional grouping was advanced by Spector et al. (2006), who grouped CWBs into five dimensions: abuse, production deviance, sabotage, theft, and withdrawal. CWBs can also be classified on the basis of the severity of the acts, ranging from minor (lying) to severe (sabotage).

Although the main concern of scholars and business managers is on the negative side of CWBs, these can be classified as both negative and positive. In line with the former, Gallperin (2002) presented the word "constructive deviance", which occurs when employees engage in certain acts that advance the organization's well-being. For instance, workers who engage in whistle-blowing perhaps do so to expose certain dysfunctional aspects of individuals so as to place such illicit practices under the control of the organization.

\subsection{Demographic Characteristics and Counterproductive Work Behavior}

A number of studies have investigated the relationship between demographic characteristics and CWBs (Henle, 2005; Hershcovis, Turner, Barling, Arnold, Dupre, Inness, and Sivanathan, 2007; Paul-Titus, 2009). For instance, a metaanalysis done by Lau, Au, and Hu (2003) showed that age, sex, and marital status were all valid predictors of different CWBs. In terms of a comparison between developed countries and developing countries, Hershcovis et al. (2007) reported that in the former gender was a stronger predictor of interpersonal aggression (a form of CWB). They further noted that men being more forceful than women, they have more tendency to engage in CWBs. Henle (2005) discovered that gender and age were associated to deviant workplace behavior, while tenure of employment was not significantly correlated with it. A study conducted by Sackett, Berry, Wiemann, and Laczo (2006) reported that gender, race, age, marital status, educational qualification, occupational area, hours of work, years spent on the job, and career tenure are significantly correlated to both composite organizational citizenship behavior and counterproductive work behaviors. 


\section{Research Methodology}

\subsection{Research Design}

The study adopts causal research design using quantitative research approach. The choice of this approach is based on the fact that the objective of this study is to deduce the cause and effect relationships to be found between the variables under investigation. Hence, causal research design is particularly suited to achieve the stated objective because it has the potential to demonstrate that a change in one variable causes some predictable change in another variable (Malhotra, 1999).

\subsection{Population, Sample Size, and Sampling Technique}

The population of the study consisted of employees of three selected parastatals (Nigerian Ports Authority, Nigerian Maritime Administration and Safety Agency, and Nigerian Shippers Council). For the purpose of this study, a targeted sample size of one thousand employees across the selected parastatals was surveyed. 400 were selected at Nigerian Ports Authority and 300 at both Nigerian Maritime Administration and Safety and Nigerian Shippers Council of Nigeria. Available statistics at the Federal Ministry of Transport confirm that Nigerian Ports Authority has bigger staff strength than the other two parastatals, which explains the disparity in the sample selection. This study used multistage sampling technique. Firstly, disproportionate quota sampling technique was adopted to select the sampled respondents on the basis of the strength of the parastatals surveyed in this study. In the second stage, purposive sampling technique often denoted as judgmental sampling - was used to select the respondents that participated in the survey based on their understanding of the phenomena under investigation. Lastly, convenience sampling was used to survey the respondents that are available and willing to participate in the survey. The target sample cut across the managerial, senior, and junior staff of the selected parastatals.

\subsection{Measures, Sources of Data, and Instrumentation}

The major variables investigated in this study are counterproductive work behavior (CWB) and socio-demographic characteristics. Measures used to evaluate CWB were adapted from Spector et al. (2006) - a total 19 descriptions of CWB involving both CWB-I (CWB targeted at individuals) and CWB-O (CWB-targeted at the organization). Examples from each category are: making use of organization property for personal use, withholding of effort, falsification of accounts for personal gain, gossiping about coworkers, and harassment among others. General 
demographic information that was gathered from participants in this study consists of gender, age, level of education, marital status, and employee cadre. The primary data were collected using a self-administered questionnaire, which is the most common instrument used in a survey research, especially where the investigator is conversant with the variables under investigation (Beiley, 1994). The choice of questionnaire is believed to offer respondents greater anonymity (Cooper \& Schneidler, 2003) and more cost effectiveness (Struwig \& Stead, 2001). Respondents were asked to rate their response on a five-point Likert scale ranging from 1 = "strongly disagree" to $5=$ "strongly agree". Validity and reliability of the research instrument were undertaken. The questionnaire was subjected to validity testing through content validity. The researchers sought the opinion of four senior academics of the Department of Business Administration, University of Lagos, while reliability testing was carried out with the help of Cronbach's Alpha. All the variables and constructs have reliability values exceeding 0.7, which shows that the instrument is reliable (Girden, 2001).

\subsection{Methods of Data Analysis and Techniques}

The data collected through the questionnaire were analyzed using the Statistical Package for Social Sciences (SPSS-19). The approaches of data analyses were conducted through descriptive (mean and percentages) and inferential statistics, using one-way analysis of variance (ANOVA) and t-test.

\section{Results and Discussion}

\subsection{Respondents' Demographic Characteristics}

Table 4.1 provides a summary of the questionnaire distribution and response rate. The desired sample size for this study was put at 1,000. A total of 811 copies of questionnaire were distributed, out of which 762 were retrieved. 49 copies of questionnaire were not retrieved and 30 were rejected due to multiple and incomplete responses, thus yielding a valid response rate of $73.2 \%$.

Table 4.1 Characteristics of employees in the Nigerian maritime industry

\begin{tabular}{llcr}
\hline Variables & Characteristics & Frequency & Percentage \\
\hline Gender & Male & 485 & 66.08 \\
\hline & Female & 249 & 33.92 \\
\hline Age (Years) & Less than 20 & 11 & 1.50 \\
\hline
\end{tabular}




\begin{tabular}{|c|c|c|c|}
\hline Variables & Characteristics & Frequency & Percentage \\
\hline & $21-29$ & 95 & 12.94 \\
\hline & $30-39$ & 198 & 27.00 \\
\hline & $40-49$ & 282 & 38.42 \\
\hline & $50-59$ & 139 & 18.94 \\
\hline & 60 and above & 9 & 1.23 \\
\hline \multirow[t]{3}{*}{ Marital Status } & Single & 128 & 17.44 \\
\hline & Married & 544 & 74.11 \\
\hline & Divorced/Separated & 62 & 8.45 \\
\hline \multirow[t]{6}{*}{ Education } & School Certificate Holder & 36 & 4.90 \\
\hline & Diploma/NCE & 149 & 20.30 \\
\hline & HND & 147 & 20.03 \\
\hline & B.Sc. & 262 & 35.70 \\
\hline & MSc/MBA & 168 & 22.90 \\
\hline & Ph.D. & 8 & 1.09 \\
\hline \multirow[t]{3}{*}{ Cadre of Employment } & Management staff & 139 & 18.94 \\
\hline & Middle-level staff & 378 & 51.50 \\
\hline & Junior staff & 217 & 29.56 \\
\hline \multirow[t]{4}{*}{ Monthly Income (Naira) } & Below 500,000 & 483 & 65.80 \\
\hline & $501,000-1,000,000$ & 174 & 23.71 \\
\hline & $1,001,000-2,000,000$ & 60 & 8.17 \\
\hline & $2,000,000$ and above & 17 & 2.31 \\
\hline
\end{tabular}

Source: field survey, 2016

There are a total number of 1,000 respondents from maritime employees involved in this study. Most of the employees are male (66.08\%), while only 33.92 percent are female. About $41.4 \%$ of the respondents are below 40 years of age. Specifically, $1.5 \%$ of employees are less than 20 years of age. About $13 \%$ are in the age range of 21 and 29 years. Respondents in the age range of 30 and 39 years constitute $27 \%$ of the work force. The highest percentage of employees $(38.42 \%)$ is to be found in the age bracket of 40 and 49 years. Whereas $18.94 \%$ are between 50 and 59 years of age, only $1.23 \%$ are 60 years and above. Overall, a high percentage of respondents is still in the active age bracket. The majority of the respondents $(74.11 \%)$ are married, $17.44 \%$ are single, and $8.45 \%$ of them are divorced/separated. The descriptive statistics of the level of education reveals that $75 \%$ are holders of higher education certificates. More specifically, 20.03\% are Higher National Diploma (HND) holders, $35.7 \%$ of the employees are university graduates with a bachelor degree, and 
$22.9 \%$ hold a master's degree. Most of the staff $(51.50 \%)$ are in the middle-level cadre of employment, while $18.94 \%$ and $29.56 \%$ are management and junior staff respectively. Expectedly, the monthly income of employees varies as follows: the majority $(65.8 \%)$ earn below 500,000.00 Naira on a monthly basis. $23.71 \%$ earn between $\$ 501,000.00$ and $\$ 1,000,000: 00,8.17 \%$ earn between $\$ 1,001,000: 00$ and $\mathrm{N} 2,000,000: 00$, while a relatively low percentage of the employees $(2.31 \%)$ earn between $\mathrm{N} 2,000,000.00$ and above.

\subsection{Testing of Hypotheses}

Counterproductive work behavior is not significantly different with respect to socio-demographic variables (such as gender, age, marital status, level of education, and income) in the Nigerian maritime industry.

\section{CWB and Gender}

Table 4.2 Descriptive statistics $-C W B$ and gender

\begin{tabular}{lcccc}
\hline What is your gender? & $\mathrm{N}$ & Mean & Std. Deviation & Std. Error Mean \\
\hline Male & 485 & 1.62 & 0.645 & 0.029 \\
\hline Female & 249 & 1.75 & 0.662 & 0.042 \\
\hline
\end{tabular}

Source: field survey, 2016

Table 4.3 CWB and gender-independent samples test

\begin{tabular}{|c|c|c|c|c|c|c|c|c|}
\hline & \multicolumn{2}{|c|}{$\begin{array}{l}\text { Levine's Test } \\
\text { for Equality } \\
\text { of Variances }\end{array}$} & \multicolumn{6}{|c|}{ T-test for Equality of Means } \\
\hline & $\mathrm{F}$ & Sig. & $\mathrm{T}$ & $\mathrm{df}$ & $\begin{array}{l}\text { Sig. (2- } \\
\text { tailed) }\end{array}$ & $\begin{array}{c}\text { Mean } \\
\text { Differ- } \\
\text { ence }\end{array}$ & $\begin{array}{l}\text { Std. } \\
\text { Error } \\
\text { Differ- } \\
\text { ence }\end{array}$ & $\begin{array}{c}95 \% \\
\text { Confidence } \\
\text { Interval of the } \\
\text { Difference }\end{array}$ \\
\hline & & & & & & & & Lower Upper \\
\hline $\begin{array}{l}\text { Equal } \\
\text { variances } \\
\text { assumed }\end{array}$ & 0.029 & 0.865 & -2.453 & 732 & 0.014 & -0.124 & 0.051 & $-0.224 \quad-0.025$ \\
\hline $\begin{array}{l}\text { Equal } \\
\text { variances not } \\
\text { assumed }\end{array}$ & & & -2.432 & 489.166 & 0.015 & -0.124 & 0.051 & $-0.225 \quad-0.024$ \\
\hline
\end{tabular}

Source: field survey, 2016

In order to ascertain whether CWB differs significantly with regard to gender in the Nigerian maritime industry, t-test of difference of means was carried out. Results 
in tables 4.2 and 4.3 show that CWB differs significantly with respect to the gender of employees in the selected sample government parastatals: $(\mathrm{df}=732, \mathrm{~T}=-2.453$, $\mathrm{p}<0.05$ ). Based on the above statistics, sub-hypothesis (1), which states that CWB does not differ significantly with respect to gender, is not supported by the finding of this study - hence, it is hypothesized that CWB significantly differs between male and female employees in the Nigerian maritime industry. The finding of this study reveals that CWB is significantly different with respect to gender in the Nigerian maritime industry. The finding of this study is in line with the studies conducted by O'Fallon and Butterfield (2005) as well as Lau, Au, and Ho (2002).

\section{CWB and Age}

Table 4.4 Descriptive statistics $-C W B$ and age

\begin{tabular}{|c|c|c|c|c|c|c|c|c|}
\hline & \multirow[t]{2}{*}{$\mathbf{N}$} & \multirow[t]{2}{*}{ Mean } & \multirow[t]{2}{*}{$\begin{array}{l}\text { Std. } \\
\text { Devia- } \\
\text { tion }\end{array}$} & \multirow[t]{2}{*}{$\begin{array}{l}\text { Std. } \\
\text { Error }\end{array}$} & \multicolumn{2}{|c|}{$\begin{array}{c}\text { 95\% Confidence } \\
\text { Interval for } \\
\text { Mean }\end{array}$} & \multirow{2}{*}{$\underset{\Xi}{\Xi}$} & \multirow{2}{*}{ 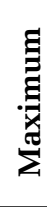 } \\
\hline & & & & & $\begin{array}{l}\text { Lower } \\
\text { Bound }\end{array}$ & $\begin{array}{l}\text { Upper } \\
\text { Bound }\end{array}$ & & \\
\hline $\begin{array}{l}\text { Below } \\
20 \text { years }\end{array}$ & 11 & 1.70 & 0.557 & 0.168 & 1.32 & 2.07 & 1 & 2 \\
\hline $21-29$ years & 95 & 1.78 & 0.763 & 0.078 & 1.62 & 1.94 & 1 & 4 \\
\hline 30-39 years & 198 & 1.53 & 0.586 & 0.042 & 1.45 & 1.61 & 1 & 3 \\
\hline 40-49 years & 282 & 1.70 & 0.687 & 0.041 & 1.62 & 1.78 & 1 & 5 \\
\hline $50-59$ years & 139 & 1.69 & 0.581 & 0.049 & 1.60 & 1.79 & 1 & 3 \\
\hline $\begin{array}{l}60 \text { years } \\
\text { and above }\end{array}$ & 9 & 1.81 & 0.487 & 0.162 & 1.44 & 2.19 & 1 & 2 \\
\hline Total & 734 & 1.67 & 0.653 & 0.024 & 1.62 & 1.71 & 1 & 5 \\
\hline
\end{tabular}

Source: field survey, 2016

Table 4.5 ANOVA - CWB and Age

\begin{tabular}{lrrrrr}
\hline & $\begin{array}{c}\text { Sum of } \\
\text { Squares }\end{array}$ & Df & $\begin{array}{c}\text { Mean } \\
\text { Square }\end{array}$ & F & Sig. \\
\hline Between groups & 5.587 & 5 & 1.117 & 2.652 & 0.022 \\
\hline Within groups & 306.717 & 728 & 0.421 & & \\
\hline Total & 312.304 & 733 & & & \\
\hline
\end{tabular}

Source: field survey, 2016

A one-way between-groups analysis of variance was conducted to explore the relationship between CWB and age. As shown in tables 4.4 and 4.5 , there is a 
significant difference at the $\mathrm{p}<0.05$ for the 6 age-groups: $\mathrm{F}(5,728)=2.662$, $\mathrm{p}$ $<.022$. Despite reaching statistical significance, the actual difference in mean scores between the groups was quite small. Post-hoc comparisons using Tukey's highly significant difference (HSD) test indicated that the mean score among the age-groups did not differ significantly. From the above statistics, sub-hypothesis (2), which states that CWB does not differ significantly with respect to age, is not supported by the finding of this study; hence, it is hypothesized that CWB significantly differs between the age-groups of employees in the Nigerian maritime industry. This finding corroborates the finding of the studies carried out by Baucus and Near (1991) and Martinko, Gundlach, and Douglas (2002). On the other hand, it contradicts the finding reported by Paul-Titus (2009) and Uchenna (2013).

\section{CWB and Marital status}

Table 4.6 Descriptive statistics $-C W B$ and marital status

\begin{tabular}{|c|c|c|c|c|c|c|c|c|}
\hline & \multirow[t]{2}{*}{$\mathrm{N}$} & \multirow[t]{2}{*}{ Mean } & \multirow[t]{2}{*}{$\begin{array}{c}\text { Std. } \\
\text { Deviation }\end{array}$} & \multirow[t]{2}{*}{$\begin{array}{l}\text { Std. } \\
\text { Error }\end{array}$} & \multicolumn{2}{|c|}{$\begin{array}{c}\text { 95\% Confidence } \\
\text { Interval for } \\
\text { Mean }\end{array}$} & \multirow{2}{*}{ 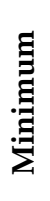 } & \multirow{2}{*}{ 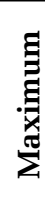 } \\
\hline & & & & & $\begin{array}{l}\text { Lower } \\
\text { Bound }\end{array}$ & $\begin{array}{l}\text { Upper } \\
\text { Bound }\end{array}$ & & \\
\hline Single & 128 & 1.59 & 0.731 & 0.065 & 1.47 & 1.72 & 1 & 4 \\
\hline Married & 544 & 1.64 & 0.629 & 0.027 & 1.59 & 1.70 & 1 & 5 \\
\hline Divorced & 23 & 2.05 & 0.735 & 0.153 & 1.73 & 2.37 & 1 & 4 \\
\hline Separated & 39 & 2.00 & 0.488 & 0.078 & 1.84 & 2.16 & 1 & 4 \\
\hline Total & 734 & 1.67 & 0.653 & 0.024 & 1.62 & 1.71 & 1 & 5 \\
\hline
\end{tabular}

Table 4.7 ANOVA - CWB and marital status

\begin{tabular}{lrrrrr}
\hline & $\begin{array}{c}\text { Sum of } \\
\text { Squares }\end{array}$ & df & $\begin{array}{c}\text { Mean } \\
\text { Square }\end{array}$ & F & Sig. \\
\hline Between groups & 8.754 & 3 & 2.918 & 7.018 & 0 \\
\hline Within groups & 303.549 & 730 & 0.416 & & \\
\hline Total & 312.304 & 733 & & & \\
\hline
\end{tabular}

A one-way between-groups analysis of variance was conducted to explore the relationship between CWB and marital status. As shown in tables 4.6 and 4.7, there is a significant difference at the $\mathrm{p}<0.05$ for the 4 marital status groups: 
$F(3,730)=7.018, p<.000$. Despite reaching statistical significance, the actual difference in mean scores between the groups varies considerably. Similarly, post-hoc comparisons using Tukey's HSD test indicated that the mean score in the marital status values was significantly different. Based on the above results, sub-hypothesis (3), which states that CWB is not significantly different with respect to marital status, is not supported by the finding of this study; hence, it is hypothesized that CWB significantly differs concerning the marital status of employees in the Nigeria maritime industry. This finding is similar to the one reported by Robinson and Greenberg (1998) and Peterson (2002).

\section{CWB and Level of Education}

Table 4.8 Descriptive Statistics $-C W B$ and level of education

\begin{tabular}{|c|c|c|c|c|c|c|c|c|}
\hline & \multirow[t]{2}{*}{$\mathbf{N}$} & \multirow[t]{2}{*}{ Mean } & \multirow[t]{2}{*}{$\begin{array}{c}\text { Std. } \\
\text { Deviation }\end{array}$} & \multirow[t]{2}{*}{$\begin{array}{l}\text { Std. } \\
\text { Error }\end{array}$} & \multicolumn{2}{|c|}{$\begin{array}{l}95 \% \text { Confidence } \\
\text { Interval for Mean }\end{array}$} & \multirow{2}{*}{$\begin{array}{l}\Xi \\
\Xi \\
\Xi \\
\Xi\end{array}$} & \multirow{2}{*}{ 䍐 } \\
\hline & & & & & $\begin{array}{l}\text { Lower } \\
\text { Bound }\end{array}$ & $\begin{array}{l}\text { Upper } \\
\text { Bound }\end{array}$ & & \\
\hline $\begin{array}{l}\text { School certificate } \\
\text { holder }\end{array}$ & 36 & 1.61 & 0.677 & 0.113 & 1.38 & 1.84 & 1 & 4 \\
\hline Diploma & 149 & 1.69 & 0.618 & 0.051 & 1.59 & 1.79 & 1 & 3 \\
\hline HND/NCE & 147 & 1.75 & 0.680 & 0.056 & 1.64 & 1.86 & 1 & 5 \\
\hline B.Sc. & 262 & 1.60 & 0.628 & 0.039 & 1.52 & 1.67 & 1 & 4 \\
\hline MSc/MBA & 132 & 1.69 & 0.704 & 0.061 & 1.57 & 1.81 & 1 & 4 \\
\hline Ph.D. & 8 & 1.77 & 0.484 & 0.171 & 1.37 & 2.17 & 1 & 2 \\
\hline Total & 734 & 1.67 & 0.653 & 0.024 & 1.62 & 1.71 & 1 & 5 \\
\hline
\end{tabular}

Source: field survey, 2016

Table 4.9 ANOVA - CWB and level of education

\begin{tabular}{lrrccc}
\hline & $\begin{array}{c}\text { Sum of } \\
\text { Squares }\end{array}$ & df & $\begin{array}{c}\text { Mean } \\
\text { Square }\end{array}$ & F & Sig. \\
\hline Between groups & 2.654 & 5 & 0.531 & 1.248 & 0.285 \\
\hline Within groups & 309.649 & 728 & 0.425 & & \\
\hline Total & 312.304 & 733 & & & \\
\hline
\end{tabular}

Source: field survey 2016

A one-way between-groups analysis of variance was conducted to explore the relationship between CWB and level of education. As shown in tables 4.8 and 4.9 , there is no significant difference at the $\mathrm{p}>0.05$ for the 6 education groups: 
$F(5,728)=1.248, p>.285$. Despite reaching a statistically insignificant level, the actual difference in mean scores between the groups does not vary significantly. Similarly, post-hoc comparisons using Tukey's HSD test indicated that the mean score among the 6 levels of educational attainment was significantly different. From the above statistics, sub-hypothesis (4), which states that CWB is not significantly different with respect to the level of education, is supported by the finding of this study. This finding contradicts the one reported by Robinson and Greenberg (1998), who reported that an increased level of education is associated with high tendency to engage in CWB.

\section{CWB and Employee Cadre}

Table 4.10 Descriptive statistics $-C W B$ and employee cadre

\begin{tabular}{|c|c|c|c|c|c|c|c|c|}
\hline & \multirow[t]{2}{*}{$\mathbf{N}$} & \multirow[t]{2}{*}{ Mean } & \multirow[t]{2}{*}{$\begin{array}{c}\text { Std. } \\
\text { Deviation }\end{array}$} & \multirow[t]{2}{*}{$\begin{array}{l}\text { Std. } \\
\text { Error }\end{array}$} & \multicolumn{2}{|c|}{$\begin{array}{l}95 \% \text { Confidence } \\
\text { Interval for Mean }\end{array}$} & \multirow{2}{*}{$\underset{\Sigma}{\Xi}$} & \multirow{2}{*}{ 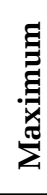 } \\
\hline & & & & & $\begin{array}{l}\text { Lower } \\
\text { Bound }\end{array}$ & $\begin{array}{l}\text { Upper } \\
\text { Bound }\end{array}$ & & \\
\hline $\begin{array}{l}\text { Management } \\
\text { staff }\end{array}$ & 139 & 1.76 & 0.649 & 0.055 & 1.65 & 1.87 & 1 & 3 \\
\hline $\begin{array}{l}\text { Middle-level } \\
\text { staff }\end{array}$ & 378 & 1.59 & 0.626 & 0.032 & 1.53 & 1.66 & 1 & 5 \\
\hline Junior staff & 217 & 1.73 & 0.689 & 0.047 & 1.64 & 1.82 & 1 & 4 \\
\hline Total & 734 & 1.67 & 0.653 & 0.024 & 1.62 & 1.71 & 1 & 5 \\
\hline
\end{tabular}

Source: field survey, 2016

Table 4.11 ANOVA - CWB and employee cadre

\begin{tabular}{lrrrrr}
\hline & $\begin{array}{c}\text { Sum of } \\
\text { Squares }\end{array}$ & Df & $\begin{array}{c}\text { Mean } \\
\text { Square }\end{array}$ & F & Sig. \\
\hline Between groups & 4.069 & 2 & 2.034 & 4.825 & 0.008 \\
\hline Within groups & 308.235 & 731 & 0.422 & & \\
\hline Total & 312.304 & 733 & & & \\
\hline
\end{tabular}

A one-way between-groups analysis of variance was conducted to explore the relationship between CWB and employee cadre. As shown in tables 4.10 and 4.11, there is significant difference at the $\mathrm{p}<0.05$ for the 3 employee cadres: $F$ $(2,731)=4.825, \mathrm{p}<.008$. Despite reaching a statistically insignificant level, the actual difference in mean scores differs slightly between the groups. Similarly, 
post-hoc comparisons using Tukey's HSD test indicated that the mean score for management and middle-level employees differs, while that of junior staff did not differ significantly from either management or middle-level employees. From the above results, sub-hypothesis (5), which states that CWB is not significantly different with respect to employee cadre, is not supported by the finding of this study; hence, it is hypothesized that CWB significantly varies with respect to employee cadre in the Nigerian maritime industry. This finding is similar to the one reported by Robinson and Greenberg (1998) and Peterson (2002).

CWB and Income Level - Descriptive

Table 4.12 Descriptive statistics - CWB and income level-descriptive

\begin{tabular}{|c|c|c|c|c|c|c|c|c|}
\hline & \multirow[t]{2}{*}{$\mathbf{N}$} & \multirow[t]{2}{*}{ Mean } & \multirow[t]{2}{*}{$\begin{array}{c}\text { Std. } \\
\text { Deviation }\end{array}$} & \multirow[t]{2}{*}{$\begin{array}{l}\text { Std. } \\
\text { Error }\end{array}$} & \multicolumn{2}{|c|}{$\begin{array}{l}95 \% \text { Confidence } \\
\text { Interval for Mean }\end{array}$} & \multirow{2}{*}{$\underset{\mathrm{Z}}{\mathbf{g}}$} & \multirow{2}{*}{ 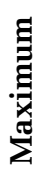 } \\
\hline & & & & & $\begin{array}{l}\text { Lower } \\
\text { Bound }\end{array}$ & $\begin{array}{l}\text { Upper } \\
\text { Bound }\end{array}$ & & \\
\hline $\begin{array}{l}\text { Below } \\
\text { \#500,000 }\end{array}$ & 483 & 1.57 & 0.633 & 0.029 & 1.51 & 1.63 & 1 & 4 \\
\hline $\begin{array}{l}¥ 501,000- \\
¥ 1,000,000\end{array}$ & 174 & 1.92 & 0.663 & 0.05 & 1.82 & 2.01 & 1 & 5 \\
\hline 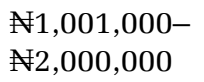 & 60 & 1.72 & 0.562 & 0.073 & 1.57 & 1.87 & 1 & 3 \\
\hline $\begin{array}{l}¥ 2,000,000 \\
\text { and above }\end{array}$ & 17 & 1.59 & 0.750 & 0.182 & 1.21 & 1.98 & 1 & 3 \\
\hline Total & 734 & 1.67 & 0.653 & 0.024 & 1.62 & 1.71 & 1 & 5 \\
\hline
\end{tabular}

Source: field survey, 2016

Table 4.13 ANOVA-CWB and income level-descriptive

\begin{tabular}{lrrccc}
\hline & $\begin{array}{c}\text { Sum of } \\
\text { Squares }\end{array}$ & Df & $\begin{array}{c}\text { Mean } \\
\text { Square }\end{array}$ & F & Sig. \\
\hline Between groups & 15.398 & 3 & 5.133 & 12.619 & 0 \\
\hline Within groups & 296.906 & 730 & 0.407 & & \\
\hline Total & 312.304 & 733 & & & \\
\hline
\end{tabular}

A one-way between-groups analysis of variance was conducted to explore the relationship between CWB and income. As shown in tables 4.12 and 4.13, there is significant difference at the $\mathrm{p}<0.05$ for the 4 income groups: $F(3,730)=12.619$, 
$\mathrm{p}<.000$. Despite reaching a statistically significant level, the actual difference in mean scores between the income groups also differs significantly. Similarly, posthoc comparisons using Tukey's HSD test indicated that the mean score for the $1^{\text {st }}$ and $2^{\text {nd }}$ income-level employees was significantly different, while that of the $3^{\text {rd }}$ and $4^{\text {th }}$ income groups did not differ significantly from either the $1^{\text {st }}$ or the $2^{\text {nd }}$ income groups. Based on the above statistics, sub-hypothesis (6), which states that CWB is not significantly different with respect to the income of the employees, is not supported by the finding of this study; hence, it is hypothesized that CWB significantly differs between the income levels of employees in the Nigerian maritime industry. This finding is similar to the one reported by Robinson and Greenberg (1998) and Peterson (2002).

\subsection{Conclusion and Implications}

This study investigates demographic characteristics and CWB in the Nigerian maritime industry. The findings of this study provide significant evidence supporting the prevalence of CWB in the public sector. No doubt, demographic characteristics highlight the importance of what underlies these deviant acts in the workplace and the role some of the variables play in determining the frequency and degree of CWB. Thus, the increasing attention and interest in CWBs is that it has potential to inhibit the attainment of organizational objectives. In particular, the prevalence of CWB in the workplace caused adverse effects on organizations in terms of declining productivity, increased costs, lost or damaged property arising from theft, and tendency for high turnover (Leblanc \& Kelloway, 2002). Another important consequence of CWBs in the workplace is the high level of employees' dissatisfaction and reported job stress (Keashly, Trott, and MacLean, 1994).

This study offers a number of implications for business managers. Accordingly, it is important for the management to establish codes of conduct so that ideal norms of respectful interaction are known and prevail at all levels of the organization to curtail the occurrence of counterproductive work behavior. The findings of this study served to assist maritime organizations to better understand what types of employees are more likely to engage in deviant behavior in specific settings and situations. A deeper understanding of CWB dimensions and the degree of its manifestation will help the government not only in curbing CWB in the workplace but in taking cognizance of these demographic variables during recruitment and employee placement. Accordingly, given that the starting point of analysis of an individual is his/her demographic profile, the management should conduct personality assessments more frequent with a view to ascertaining the demographic characteristics that have a tendency to induce CWB. Another vital implication of this study is the need to connect demographic characteristics with 
job identity and allocation of tasks. For instance, a finding of this study indicates that gender, age, marital status, employee cadre, and income are significantly related to CWBs. The immediate implication of this finding is that the prevalence of tendency to engage in CWBs is very much connected to these demographic variables; hence, the management should focus serious attention on them. On the other hand, the finding that the level of educational attainment is not significantly related to CWB portends that employees, irrespective of their level of education, are likely to engage in CWB.

\subsection{Recommendations}

In view of the significant relationship documented between some demographic characteristics in this study, business organizations should develop a mechanism for identifying and selecting their potential employees. Likewise, an organization should have a good pre-employment surveillance method to evaluate candidate background and perform a vetting that could assist in identifying employees with a high tendency to engage in deviant behavior.

Efforts should be intensified to put into practice such strategies that develop the culture of organizations in the Nigerian maritime industry. By developing a good culture, it will be much easier to modify employee behavior in a way that aligns with the goals and objectives of the organizations in particular and the maritime industry in general.

Management should give due consideration to workplace environment and ensure that it is conducive for all and sundry. By having the right climate, counterproductive work behaviors will be at the barest minimum level. Without the right organizational climate, undesirable behavior will persist and may even escalate to dangerous situations.

\section{References}

Aftab, H.; Javed, A. (2012). The impact of job stress on the counter-productive work behaviour (CWB): a case study from the financial sector of Pakistan. Interdisciplinary Journal of Contemporary Research in Business 4(7): 590-604.

Ambrose, M. L.; Seabright, M. A.; Schminke, M. (2002). Sabotage in the workplace: the role of organisational injustice. Organisational Behaviour and Human Decision Processes 89: 947-965.

Andersson, L. M.; Pearson, C. M. (1999). Tit for tat? The spiraling effect of incivility in the workplace. The Academy of Management Review 24(3): 452-471. 
Aquino, K.; Galperin, B. L.; Bennett, R. J. (2004). Social status and aggressiveness as moderator of the relationship between interactional justice and workplace CWB. Journal of Applied Psychology 34(5): 1001-1029.

Bailey, K. D. (1994). Method of social research ( $4^{\text {th }}$ ed.). New York: The Free Press. Barling, J.; Dupre, K.; Kelloway, E. K. (2009). Predicting workplace violence and aggression. Annual Review of Psychology 60: 671-692.

Baucus, M.; Near, J. (1991). Can illegal corporate behaviour be predicted? An event history analysis. Academy of Management Journal 34(1): 9-36.

Business News (2016). It is a disgrace that 27 states in Nigeria cannot pay worker's salary - Buhari. Retrieved on: August 21, 2016, from: http://www. givenbiznews.com/It is a disgrace that 27 States in Nigeria cannot pay worker's salary-Buhari.

Chang, K.; Smithikrai, C. (2010). Counterproductive behaviour at work: An investigation into reduction strategies. International Journal of Human Resource Management 21(8): 1272-1288.

Cooper, D. R.; Schindler, P. S. (2003). Business research methods ( $8^{\text {th }}$ ed.). Boston: McGraw-Hill Irwin.

Cressey, D. (1973). Other people's money. Montclair: Patterson Smith.

Deloitte Financial Advisory Services. (2008). Financial fraud: does an economic downturn mean an uptick? Deloitte Development LLC. (www.Deloitte.com).

Dineen, R. J.; Lewicki, E.C. (2006). Tomlinson supervisory guidance and behavioural integrity: relationships with employee citizenship and deviant behaviour. Journal of Applied Psychology 91(3): 622-635.

Fatima, A.; Atif, K.; Saqib, A.; Haider, A. (2012). A path model examining the relations among organisational injustice, counterproductive work behaviour and job satisfaction. International Journal of Innovation, Management and Technology 3(6): 697-701.

Fox, S.; Spector, P. E. (1999). A model of work frustration-aggression. Journal of Organisational Behaviour 20: 915- 931.

Gabriel, A. A. (n.d.). Demographic and dispositional characteristics as predictors of organisational citizenship behaviour: an appraisal of OCB in a non-English culture workgroups.

Galperin, B. L. (2002). Determinants of deviance in the workplace: an empirical examination in Canada and Mexico (Doctoral dissertation). Concordia University.

Girden, E. R. (2001). Evaluating research articles (2 ${ }^{\text {nd }}$ ed.). London: SAGE.

Greenberg, J. (1990). Employee theft as a reaction to underpayment inequity: the hidden cost of pay cuts. Journal of Applied Psychology 75: 561-568.

Henle, C. A. (2005). Predicting workplace deviance from the interaction between organisational justice and personality. Journal of Managerial Issues 17(2): 247263. 
Hershcovis, M. S.; Turner, N.; Barling, J.; Arnold, K. A.; Dupre, K. E.; Inness, M.; Sivanathan, N. (2007). Predicting workplace aggression: a meta-analysis. Journal of Applied Psychology 92: 228-238.

Hiriyappa, B. (2008). Organisational Behaviour. India: New Age International PVT Ltd.

Hoel, H.; Rayner, C.; Cooper, C. L. (1999). Workplace bullying. In: Cooper, C. L.; Robertson, I. T. (eds.), International review of industrial and organisational psychology. Chichester, UK: Wiley. 195-230.

Idiakheua, E. O.; Obetoh, G. I. (2012). Counterproductive work behaviour of Nigerians: an insight into make-up theory. Interdisciplinary Journal of Contemporary Research in Business 4(7): 10.

Keashly, L. (1998). Emotional abuse in the workplace: Conceptual and empirical issues. Journal of Emotional Abuse 1(1): 85-117.

Keashly, L.; Trott, V.; MacLean, L. M. (1994). Abusive behaviour in the workplace: a preliminary investigation. Violence and Victims 9: 341-357.

Kelloway, E. K. (2010). Counterproductive work behaviour as protest. Human Resource Management Review 20: 18-25.

Lasisi, O. J.; Okuneye, M. Y.; Shodiya, O. A. (2014). Antecedents of counter work behavior in public sector organisations: evidence from Nigeria. Kuwait Chapter of Arabian Journal of Business and Management Review 3(9): 58-65.

Lau, V. C. S.; Au, W. T.; Ho, J. M. C. (2002). A qualitative and quantitative review of antecedents of counterproductive behaviour in organisations. Journal of Business and Psychology 18(1): 73-99.

Lawrence, T. B.; Robinson, S. L. (2007). Ain't misbehavin: workplace deviance as organisational resistance. Journal of Management 33: 378-394.

LeBlanc, M.; Kelloway, E. (2002). Predictors and outcomes of workplace violence and aggression. Journal of Applied Psychology 87(3): 444-453.

Malhotra, N. K. (1999). Marketing research: an applied orientation ( $3^{\text {rd }}$ ed.). New Jersey: Prentice Hall.

Mario, G. (2012). Counterproductive work behaviours and moral disengagement. Doctorate in Pro-sociality, Innovation and Collective Efficacy in Educational and Organisational Contexts. XXIV Course, Sapienza Universita Di Roma.

Martinko, M. J.; Gundlach, M. J.; Douglas, S. C. (2002). Toward an integrative theory of counterproductive workplace behaviours. A causal reasoning perspective. International Journal of Selection and Assessment 10: 36-50.

Nagle, K. J. (2009). Seaports deliver prosperity. AAPA Seaports Magazine winter. Retrieved on: August 11, 2015, from: http://www.aapaports.org/Publications/ SeaportsDetail.cfm?itemnumber=13112\#seaportsarticle.

Neuman, J. H.; Baron, R. A. (1997). Aggression in the workplace. In: Giacalone, R. A.; Greenberg, J. (eds.), Antisocial behaviour in organisations. Thousand Oaks, CA: Sage. 
O’Fallon, M. J.; Butterfield, K. D. (2005). A review of the empirical ethical decisionmaking literature: 1996-2003. Journal of Business Ethics 59: 375-413.

Paul-Titus, R. (2009). Deviant workplace behaviour in organisations: antecedents, influences, and remedies. International Business Administration - University of Vienna.

Pearson, C. M.; Andersson, L. M.; Porath, C. L. (2005). Workplace incivility. In: Fox, S.; Spector, P. E. (eds.), Counterproductive workplace behaviour: Investigations of actors and targets. Washington, DC: APA. 177-200.

Pelin, K.; Funda, E. U. (2013). The effect of organisational study on the employees of manufacturing. The Macrotheme Review 2(4): 144-160.

Penney, L. M.; Spector, P. E. (2005). Job stress, incivility, and counterproductive work behaviour (CWB): the moderating role of negative affectivity. Journal of Organisational Behaviour 26: 777-796.

Peterson, D. (2002). The relationship between unethical behaviour and the dimensions of the ethical climate questionnaire. Journal of Business Ethics 41: 313-326.

Robinson, S. L.; Bennett, R. J. (1995). A typology of deviant workplace behaviours: A multidimensional scaling study. Academy of Management Journal 38: $555-572$.

Robinson, S. L.; Greenberg, J. (1998). Employees behaving badly: dimensions, determinants, and dilemmas in the study of workplace deviance. Journal of Organisational Behaviour (1986-1998) 5(6): 1-30.

Sackett, P. R. (2002). The structure of counterproductive work behaviours: dimensionality and relationships with facets of job performance. International Journal of Selection \& Assessment 10(1-2): 01-11.

Sackett, P. R.; Berry, C. M.; Wiemann, S. A.; Laczo, R. M. (2006). Citizenship and counterproductive work behaviour: clarifying relationships between the two domains. Human Performance 19: 441-464.

Shamsudin, F.; Subramaniam, C.; Ibrahim, H. (2011). HR practices and deviant behaviour at work: an exploratory study. 2011 International Conference on Business and Economics Research.

Sharizan, S.; Abdul Rahman, A. R.; Noor, A. D. (2013). Relationship between person organization fit, psychological contract violation on counterproductive work behaviour. International Journal of Business and Social Science 4(4): 173-183.

Skarlicki, D. P.; Folger, R. (1997). Retaliation in the workplace: the roles of distributive, procedural, and interactional justice. Journal of applied psychology 82: 434-443.

Spector, P. E.; Fox, S. (2005). A model of counterproductive work behaviour. In: Fox, S.; Spector, P. E. (eds.), Counterproductive workplace behaviour: investigations of actors and targets. Washington, DC: APA. 151-174. 
Spector, P. E.; Fox, S.; Penney, L. M.; Bruursema, K.; Goh, A.; Kessler, S. (2006). The dimensionality of counter-productivity: are all counterproductive behaviours created equal? Journal of Vocational Behaviour 68(3): 446-460.

Struwig, F. W.; Stead, G. B. (2001). Planning, designing and reporting research. Cape Town: Pearson.

Uchenna, C. O. (2013). Counterproductive work behaviour among employees in emotionally demanding jobs: the roles of perceived organisational support, job burnout, and age. Nigerian Journal of Applied Behavioural Sciences 1: 105-114. Vardi, Y.; Weitz, E. (2004). Misbehaviour in organisations: theory, research, and management. NJ: London: Lawrence Erlbaum Associates.

Vigoda, E. (2002). Stress-related aftermaths to workplace politics: the relationships among politics, job distress and aggressive behaviour in organisations. Journal of Organisational Behaviour 23(5): 571-589.

Yang, J.; Diefendorf, J. M. (2009). The relations of daily counterproductive workplace behaviours with emotions, situational antecedents, and personality moderators: a diary study in Hong Kong. Personnel Psychology 62(2): 259-295.

Zapf, D.; Einarsen, S. (2005). Mobbing at work: escalated conflicts in organisations. In: Spector, P. E.; Fox, S. (eds.), Counterproductive work behaviour: investigations of actors and targets. Washington, DC, US: American Psychological Association. 237-270. 